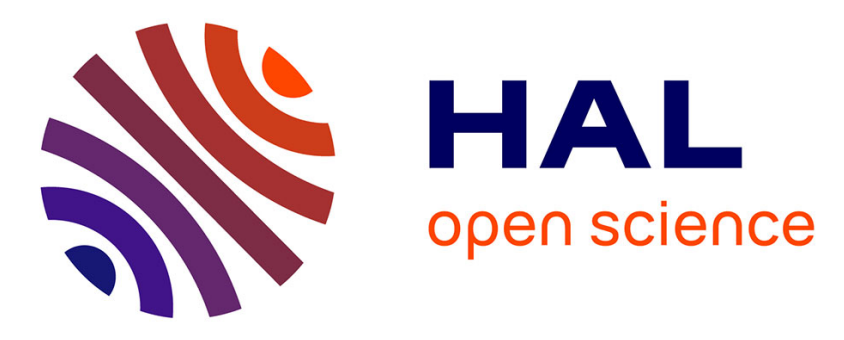

\title{
Point mutations in human guanylate kinase account for acquired resistance to anticancer nucleotide analogue PMEG
}

\author{
Helena Mertlíková-Kaiserová, Michaela Rumlová, Eva Tlouštová, Eliška \\ Procházková, Antonín Holý, Ivan Votruba
}

\section{To cite this version:}

Helena Mertlíková-Kaiserová, Michaela Rumlová, Eva Tlouštová, Eliška Procházková, Antonín Holý, et al.. Point mutations in human guanylate kinase account for acquired resistance to anticancer nucleotide analogue PMEG. Biochemical Pharmacology, 2011, 10.1016/j.bcp.2011.04.002 . hal-00703550

\section{HAL Id: hal-00703550 \\ https://hal.science/hal-00703550}

Submitted on 3 Jun 2012

HAL is a multi-disciplinary open access archive for the deposit and dissemination of scientific research documents, whether they are published or not. The documents may come from teaching and research institutions in France or abroad, or from public or private research centers.
L'archive ouverte pluridisciplinaire HAL, est destinée au dépôt et à la diffusion de documents scientifiques de niveau recherche, publiés ou non, émanant des établissements d'enseignement et de recherche français ou étrangers, des laboratoires publics ou privés. 


\section{Accepted Manuscript}

Title: Point mutations in human guanylate kinase account for acquired resistance to anticancer nucleotide analogue PMEG

Authors: Helena Mertlíková-Kaiserová, Michaela Rumlová, Eva Tlouštová, Eliška Procházková, Antonín Holý, Ivan Votruba

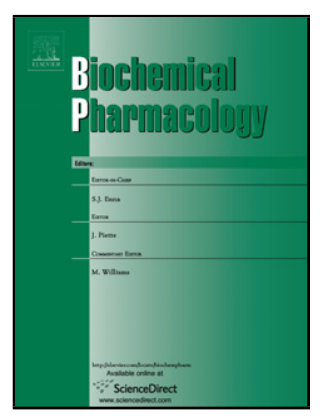

PII: S0006-2952(11)00221-8

DOI: doi:10.1016/j.bcp.2011.04.002

Reference: BCP 10874

To appear in: $\quad B C P$

Received date: $\quad$ 17-2-2011

Revised date: $\quad 1-4-2011$

Accepted date: $\quad 4-4-2011$

Please cite this article as: Mertlíková-Kaiserová H, Rumlová M, Tlouštová E, Procházková E, Holý A, Votruba I, Point mutations in human guanylate kinase account for acquired resistance to anticancer nucleotide analogue PMEG, Biochemical Pharmacology (2010), doi:10.1016/j.bcp.2011.04.002

This is a PDF file of an unedited manuscript that has been accepted for publication. As a service to our customers we are providing this early version of the manuscript. The manuscript will undergo copyediting, typesetting, and review of the resulting proof before it is published in its final form. Please note that during the production process errors may be discovered which could affect the content, and all legal disclaimers that apply to the journal pertain. 
Title page

Point mutations in human guanylate kinase account for acquired resistance to anticancer nucleotide analogue PMEG

Helena Mertlíková-Kaiserová, Michaela Rumlová, Eva Tloušt’ová, Eliška Procházková, Antonín Holý, Ivan Votruba

Institute of Organic Chemistry and Biochemistry, Academy of Sciences of the Czech Republic, Flemingovo nám. 2, 16610 Prague, Czech Republic

\section{Corresponding author:}

Helena Mertlíková-Kaiserová

Institute of Organic Chemistry and Biochemistry

Academy of Sciences of the Czech Republic

Flemingovo nám. 2

16610 Prague 6

Czech Republic

Tel: +420 220183114

Fax: +420 220183560

E-mail: kaiserova@uochb.cas.cz 
Acyclic nucleotide analogue PMEG represents promising drug candidate against lymphomas. In the present work we describe the ability of PMEG to induce resistance and we elucidate the mechanisms involved in this process. CCRF-CEM T-lymphoblastic cells resistant to either PMEG or its 6-amino congener PMEDAP were prepared and assayed for the expression of membrane transporters, PMEG and PMEDAP uptake and intracellular metabolism. Genes for guanylate kinase (GUK) and adenylate kinase (AK) isolated from PMEG- and PMEDAPresistant cells were sequenced and cloned into mammalian expression vectors. PMEGresistant cells were transfected with GUK vectors and catalytic activities of GUKs isolated from PMEG-sensitive and resistant cells were compared. PMEG phosphorylation to PMEG mono- and diphosphate was completely impaired in resistant cells. GUK obtained from PMEG-resistant cells revealed two point mutations $\mathrm{S}^{35} \mathrm{~N} \mathrm{~V}^{168} \mathrm{~F}$ that significantly suppressed its catalytic activity. Transfection of resistant cells with wtGUK led to the recovery of phosphorylating activity as well as sensitivity towards PMEG cytotoxicity. No differences in PMEG uptake have been found between sensitive and resistant cells. In contrast to GUK no changes in primary sequence of AK isolated from PMEDAP resistant cells were identified. Therefore, resistance induced by PMEDAP appears to be conferred by other mechanisms. In conclusion, we have identified GUK as the sole molecular target for the development of acquired resistance to the cytotoxic nucleotide PMEG. Therefore, PMEG is unlikely to cause cross-resistance in combination therapeutic protocols with most other commonly used anticancer drugs.

Keywords. Resistance, acyclic nucleoside phosphonates, PMEG, PMEDAP, guanylate kinase, adenylate kinase. 
Abbreviations. PMEG, 9-[2-(phosphonomethoxyethyl)guanine]; PMEDAP, 9-[2(phosphonomethoxyethyl)diaminopurine]; PMEA, 9-[2-(phosphonomethoxyethyl)adenine]; GUK, guanylate kinase; AK, adenylate kinase; GMP, guanosine monophosphate; AMP, adenosine monophosphate; ANP, acyclic nucleoside phosphonate; CdA, 2-chloro-2'deoxyadenosine (cladribine); FUDR, 5-fluoro-2'-deoxyuridine 


\section{Introduction}

Nucleoside and nucleotide analogs rank among clinically important drugs in anticancer chemotherapy. Although acyclic nucleoside phosphonates (ANP) have now been predominantly recognized as efficient antiviral agents [1], their anticancer potency is also of interest [2]. 9-[2-(phosphonomethoxyethyl)guanine (PMEG) and 9-[2(phosphonomethoxyethyl)diaminopurine (PMEDAP) (Fig. 1) represent the ANP with enhanced cytotoxic properties and possible use as novel antitumor compounds [3,4]. PMEG, in a form of a double prodrug GS-9219, has been previously shown to be active against NonHodgkin's lymphoma in dogs [5], while PMEDAP significantly prolonged survival of SD-rats with spontaneous lymphoma [6]. The advantage of ANP over conventional nucleotides lies in the chemical and metabolic stability of phosphonic bond. ANP bypass first-step phosphorylation, nevertheless they still require phosphorylation to ANPp and ANPpp to be active [7]. These reactions are catalyzed by specific nucleoside monophosphate kinases (NMPK) and relatively non-specific nucleoside diphosphate kinase (NDPK). We have previously demonstrated that PMEG is phosphorylated by guanosine monophosphate kinase (guanylate kinase, GUK) [8] while PMEDAP is activated by the mitochondrial isoform of adenosine monophosphate kinase (adenylate kinase 2, AK2) but not its cytosolic AK1 counterpart in L1210 cells [9]. These studies also indicated that both PMEG and PMEDAP were much weaker substrates for their respective phosphorylating enzymes compared to the natural substrates GMP and AMP, respectively.

Acquired resistance to chemotherapy upon prolonged or repeated administration is a serious issue complicating the treatment. Understanding the mechanisms leading to its development is crucial for designing strategies how to prevent or delay its onset as well as for predicting possible cross-resistance with other chemotherapeutics used within the same therapeutical protocol. Frequently, resistance occurs as a consequence of decreased 
intracellular concentration of the drug due to up-regulation of drug efflux proteins such ATPbinding cassette transporters (P-gp, MRP1, MRP4, MRP5) [10]. While nucleotides are not recognized as P-gp substrates, there is some evidence that MRP4 and/or MRP5 transporters may play role in resistance to 9-[2-(phosphonomethoxyethyl]adenine (PMEA) [11] and PMEDAP [12]. Another possible cause of the resistance that has been described in some anticancer nucleosides is represented by the defective metabolic activation, i.e. phosphorylation, by the individual kinases [13] or enhanced deactivation by nucleotidases [14]. Other means of chemoresistance development include alterations in various signaling pathways such as protein kinase signaling [15].

This work aims to elucidate the mechanisms responsible for the development of resistance in CCRF-CEM lymphoblastic cells following long-term exposure to PMEG. Emphasis has been placed on the role of intracellular transport and metabolism. The question whether there might be interferences with the cytostatic efficiency of other commonly used chemotherapeutics has also been addressed.

\section{Methods}

\subsection{Materials}

PMEG and PMEDAP were prepared according to the previously published procedures [16]. The identity and purity of the compounds was verified by means of NMR spectroscopy. Stock solutions of the compounds were prepared by dissolving them in water to $15 \mathrm{mM}$ concentration. Doxorubicin, etoposide, cladribine, 5-fluoro-2'-deoxyuridine, 1,1,2-trichloro1,2,2-trifluoroethane, trioctylamine, mineral oil, silicone oil DC 702, streptomycin, penicillin 
G, PBS and RPMI-1640 medium were purchased from Sigma-Aldrich (St. Louis, MO, USA), fetal calf serum was obtained from PAA Laboratories $\mathrm{GmbH}$ (Pasching, Austria). [8$\left.{ }^{3} \mathrm{H}\right] \mathrm{PMEG}$ and $\left[8-{ }^{3} \mathrm{H}\right] \mathrm{PMEDAP}$ were prepared at the Laboratory of Radioisotopes at IOCB [17], [U- $\left.{ }^{14} \mathrm{C}\right] \mathrm{GMP}$ and $\left[8^{-14} \mathrm{C}\right] \mathrm{AMP}$ were purchased from MP Biomedicals (Solon, OH, USA). Soluene $350^{\circledR}$ was provided by Perkin Elmer (Waltham, MA, USA), TCA and salts for buffer preparations were from Serva (Heidelberg, Germany), LY335979 and MK571 were kindly provided by Gilead Sciences (Foster City, CA, USA). Oligonucleotides (PCR primers) used in this study were custom-synthesized by Sigma-Aldrich.

\subsection{Cell culture}

CCRF-CEM cells (ATCC CCL 119) were cultured under a humidified atmosphere containing $5 \% \mathrm{CO}_{2}$ at $37^{\circ} \mathrm{C}$. They were grown in T-25 flasks in RPMI-1640 medium supplemented with $10 \%(\mathrm{v} / \mathrm{v})$ fetal calf serum, $200 \mu \mathrm{g} \cdot \mathrm{mL}^{-1}$ of streptomycin, $200 \mathrm{U} \cdot \mathrm{mL}^{-1}$ of penicillin $\mathrm{G}$ and 4 $\mathrm{mM}$ glutamine. Resistant cells were obtained by continuous exposure of the cells to increasing concentrations of PMEG or PMEDAP starting at their respective $\mathrm{GIC}_{50}(1 \mu \mathrm{M}$ and $10 \mu \mathrm{M}$ ), and reaching $90 \mu \mathrm{M}$ and $300 \mu \mathrm{M}$, resp. after 12 months. Cells were subcultured twice a week by centrifugation and fresh media with the compounds were added each time. Cell growth and viability was monitored using Countess ${ }^{\circledR}$ Automated Cell Counter (Invitrogen, Paisley, UK) following Trypan blue (0.4\%) staining.

\subsection{Cytotoxicity evaluation}

Sensitivity of the cells to various chemotherapeutics (PMEG, PMEDAP, doxorubicin, etoposide, cladribine, FUDR) was assessed with the use of XTT cell proliferation kit II (Roche Diagnostics GmbH, Mannheim, Germany) according to manufacturer's instructions. Briefly, cells were seeded in a 96-well plate in a density of 10000 cells per well and left to 
rest $\mathrm{o} / \mathrm{n}$. The tested compounds were added to the culture media the next day and incubated for $72 \mathrm{~h}$ before XTT dye was added. The absorbance at $495 \mathrm{~nm}$ was read after $1 \mathrm{~h}$. $\mathrm{IC}_{50}$ values were determined by GraphPad Prism version 5.00 for Windows (GraphPad Software, La Jolla, CA, USA).

\subsection{Intracellular transport of $\left[{ }^{3} H\right]-P M E G$ and $\left[^{3} H\right]-P M E D A P$}

CCRF-CEM cells were washed by centrifugation ( $250 \mathrm{x} \mathrm{g}, 5 \mathrm{~min})$ in PBS and resuspended in RPMI medium w/o any additives. The cell suspension was distributed into microtubes in 450$\mu \mathrm{l}$ aliquots and $50 \mu \mathrm{l}\left[{ }^{3} \mathrm{H}\right] \mathrm{PMEG}$ or $\left[{ }^{3} \mathrm{H}\right] \mathrm{PMEDAP}$ was added to the desired concentration. Incubation was done at $37^{\circ} \mathrm{C}$ in a controlled $\mathrm{CO}_{2}$-incubator using a rotary stirrer. At indicated time intervals the uptake process was terminated by centrifugation at $5300 \mathrm{x} \mathrm{g}$ for $1 \mathrm{~min}$ through an oil layer (a mixture of silicone and mineral oil at final specific density of $1.05 \mathrm{~g} / \mathrm{ml}$ of $150 \mu \mathrm{l}$ volume). The cell sediment was washed by centrifugation $(5300 \mathrm{x} \mathrm{g}, 1 \mathrm{~min})$ in $1 \mathrm{ml}$ PBS, solubilized with Soluene ${ }^{\circledR}$ tissue solubilizer o/n and radioactivity was counted in a toluene scintillator ( $4 \mathrm{ml}$ per sample). The intracellular volume of CCRF-CEM for calculation of the actual cytoplasmic concentration of PMEG and PMEDAP was $3.38 \mathrm{ml} / 10^{7}$ cells as determined previously (Olšanská et al., 1997).

\subsection{Intracellular metabolism of $\left[^{3} H\right] P M E G$ and $\left[^{3} H\right] P M E D A P$ in sensitive and resistant cells}

The cells were washed with PBS, resuspended in $20 \mathrm{ml}$ of RPMI growth medium at a concentration of $1 \times 10^{6}$ per ml and incubated with $2.5 \mu \mathrm{M}\left[{ }^{3} \mathrm{H}\right] \mathrm{PMEG}(200 \mu \mathrm{Ci})$ or $15 \mu \mathrm{M}$ $\left[{ }^{3} \mathrm{H}\right] \mathrm{PMEDAP}(200 \mu \mathrm{Ci})$ in a $\mathrm{CO}_{2}$-incubator for $24 \mathrm{~h}$ at $37^{\circ} \mathrm{C}$. Cells were then washed in $1 \mathrm{ml}$ PBS and pelleted by centrifuging at $250 \mathrm{x}$ g for $1 \mathrm{~min}$. The sediment was resuspended in 200 $\mu 1$ of deionized water and subjected to three freeze-thaw cycles. $200 \mu 1$ of $10 \%$ trichloroacetic acid (TCA) was then added. After $10 \mathrm{~min}$ of vigorous shaking at $4{ }^{\circ} \mathrm{C}$ the precipitate was 
sedimented at $11000 \mathrm{x} \mathrm{g}(5 \mathrm{~min})$. TCA was extracted from the supernatant with $400 \mu \mathrm{l}$ of a mixture of 1,1,2-trichloro-1,2,2-trifluoroethane-trioctylamine $(4: 1, \mathrm{v} / \mathrm{v})$. The two phases were separated by centrifugation at $11000 \mathrm{x}$ g for $5 \mathrm{~min}$ and $50 \mu \mathrm{l}$ of the upper aqueous layer was applied to Supelcosil LC-18T HPLC column $(150 \times 4.6 \mathrm{~mm}, 3 \mu \mathrm{m})$ and analyzed for

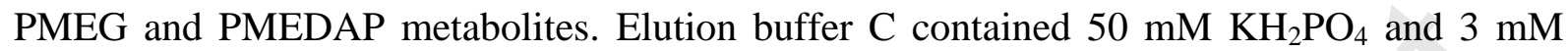
tetrabutylammonium hydrogensulphate at $\mathrm{pH}$ 3.1. Buffer D was identical with $\mathrm{C}$ except for the addition of $30 \%(\mathrm{v} / \mathrm{v})$ acetonitrile. The column was eluted with a linear gradient from 15 to $60 \%$ of buffer $\mathrm{D}$ for $25 \mathrm{~min}$ at the flow rate of $1 \mathrm{ml} / \mathrm{min}$. $0.5-\mathrm{ml}$ fractions were collected and radioactivity was counted in an aqueous scintillator (4 $\mathrm{ml}$ per sample). PMEG, PMEGp, PMEGpp, PMEDAP, PMEDAPp and PMEDAPpp were identified with the aid of authentic standards.

\subsection{Preparation of crude cellular extracts and in vitro phosphorylation studies}

$1.5 \times 10^{9}$ cells were washed with PBS and suspended in $1.5 \mathrm{ml}$ of $50 \mathrm{mM}$ Tris-HCl buffer $\mathrm{pH}$ 7.4 containing $1 \mathrm{mM}$ DTT, $5 \mathrm{mM} \mathrm{MgCl}$, protease inhibitor cocktail (Sigma-Aldrich) and 0.4\% NP-40. Cells were sonicated $3 \times 5 \mathrm{~s}$ and homogenized in a Dounce homogenizer. Homogenate was centrifuged at $30000 \mathrm{x} \mathrm{g}$ for $30 \mathrm{~min}$. Supernatant was incubated with streptomycin sulphate for $1 \mathrm{~h}$ to remove nucleic acids and centrifuged at $30000 \mathrm{x} \mathrm{g}$ for 30 min. Resulting crude cell extract (supernatant) was desalted on PD-10 columns (GE Healthcare), aliquoted and stored at $-80{ }^{\circ} \mathrm{C}$. Protein content was determined by the BCA kit (Sigma-Aldrich), according to the manufacturer's instructions. Reaction mixture (20 $\mu \mathrm{l})$ for in vitro phosphorylation of PMEG or guanosine monophosphate (GMP) contained $100 \mathrm{mM}$ TRIS-HCl buffer pH 7.5, 4 mM ATP, 10 mM MgCl $2,1 \mathrm{mM}$ DTT, $100 \mathrm{mM} \mathrm{KCl,} 5 \mu \mathrm{Ci}$ $\left[{ }^{3} \mathrm{H}\right] \mathrm{PMEG}$ or $0.05 \mu \mathrm{Ci}\left[{ }^{14} \mathrm{C}\right] \mathrm{GMP}$, varying concentration of cold PMEG or GMP and $10 \mu \mathrm{l}$ of cell extract $(7-9 \mathrm{mg} / \mathrm{ml}$ protein for PMEG phosphorylation, $0.1 \mathrm{mg} / \mathrm{ml}$ protein for GMP 
phosphorylation). Reaction mixture $(20 \mu \mathrm{L})$ for in vitro phosphorylation of PMEDAP or adenosine monophosphate (AMP) contained $40 \mathrm{mM}$ HEPES buffer $\mathrm{pH} 8.0,1 \mathrm{mM} \mathrm{MgCl}_{2}, 0.2$ mM ATP, $2 \mathrm{mM}$ mercaptoethanol, $0.4 \mathrm{mg} / \mathrm{ml} \mathrm{BSA}, 5 \mathrm{mM}$ creatine phosphate, $0.05 \mathrm{mg} / \mathrm{ml}$ creatine kinase, $5 \mu \mathrm{Ci}\left[{ }^{3} \mathrm{H}\right] \mathrm{PMEDAP}$ or $0.05 \mu \mathrm{Ci}\left[{ }^{14} \mathrm{C}\right] \mathrm{AMP}$, varying concentration of cold PMEDAP or AMP and $10 \mu \mathrm{l}$ of cell extract $(7-9 \mathrm{mg} / \mathrm{ml}$ for PMEDAP phosphorylation, diluted to $0.01 \mathrm{mg} / \mathrm{ml}$ protein for AMP phosphorylation). The reactions took place at $30{ }^{\circ} \mathrm{C}$ for $10 \mathrm{~min}$ and were terminated at indicated time by spotting a $2 \mu \mathrm{l}$ aliquot onto a PEIcellulose TLC plate prespotted with authentic standards and developed in $0.5 \mathrm{M} \mathrm{KH}_{2} \mathrm{PO}_{4}$. The spots were visualized under UV light and radioactivity was counted in a scintillation counter.

\subsection{Cloning and sequencing of GUK and AK genes}

RNA isolation, quality control and cDNA synthesis were performed as described previously [18]. cDNA was prepared from total mRNAs isolated from PMEG sensitive or resistant CCRF-CEM cells, and PMEDAP sensitive or resistant CCRF-CEM cells. The GUK1 gene was isolated from PMEG sensitive and resistant cells using GUK1 specific primers, 5’AAA GAA TTC GGA TGT CGG GCC CCA GGC CTG TG and 3’AAA CTC GAG TCA GGC GCC GGT CCT TTG AGC. AK2 A and B isoforms were isolated from PMEDAP sensitive and resistant cells using the same primer at the 5'end 5'AAA TGG CCA TGG CTC CCA GCG TGC CAG C and 3`AK2 specific primers: AAA CTC GAG TTA GAT AAA CAT AAC CAA GTC TTT AC for AK2A and AAA CTC GAG CTA GGA TGT GGC TTT GGA GAA GG for AK2B, respectively. PCR was carried out using Phusion polymerase (Finnzymes, Espoo, Finland). The PCR products were cloned into HA-pCMV vector (Clontech, Mountain View, CA, USA). Five independent clones of each isolate were sequenced. The amino acid alignment was done using Multalin software at http://multalin.toulouse.inra.fr/multalin/multalin.html. 


\subsection{Transfection of the cells with wt and SV/NF GUK DNA}

$2 \mathrm{ml}$ of RPMI medium w/o antibiotics, containing 10\% FCS were placed into each well of the 6-well plate and left to equilibrate at $37{ }^{\circ} \mathrm{C}$ in a $\mathrm{CO}_{2}$ incubator for 2-3 hours. Sensitive and PMEG-resistant cells were harvested by centrifugation ( $250 \times \mathrm{g}, 5 \mathrm{~min})$, washed with PBS and suspended in Resuspendation buffer $\mathrm{R}$ (Neon ${ }^{\circledR} 10 \mu \mathrm{L}$ kit, Invitrogen) containing $0.1 \mu \mathrm{g} / \mu \mathrm{l}$ DNA or PBS (mock) to a concentration of 200000 cells/ $\mu 1.10 \mu 1$ of cell suspension were aspirated into a Neon ${ }^{\circledR}$ tip and subjected to three pulses of $1325 \mathrm{~V}$ for $10 \mathrm{~ms}$ using Neon ${ }^{\circledR}$ Transfection System (Invitrogen). Transfected cells were transferred in the prewarmed medium in the culture plate and incubated for $48 \mathrm{~h}$. After that, cells were lysed either in the protein lysis buffer for immunoblotting experiments or in the CHAPS lysis buffer for the assays of enzymatic activity. $30000 \mathrm{x}$ g supernatants were immediately used for determination of protein content and GUK and AK activity as described in 2.6.

\section{9. $R T-q P C R$ analysis of gene expression}

GUK1, AK2 and $\beta$-actin mRNA expression was quantified using DyNamo ${ }^{\circledR}$ kit (Finzymmes) and DNA Engine Opticon ${ }^{\circledR} 2$ thermocycler (BioRad, Herkules, CA, USA). The PCR reactions $(25 \mu \mathrm{l})$ were run in triplicates and contained $2 \mu \mathrm{l}$ of template cDNA and $0.3 \mu \mathrm{M}$ of the following primers: GUK1(FP) - CTC CTC TGT GGC TCT GGA AG; GUK1(RP) - CTC TTC AGC AGG GTG CTC TT; AK2(FP) - TAT CCT AAA GGC ATC CGG G; AK2(RP) CCC CAG TAG CTA AAT GGC AG. The thermocycling program included an initial denaturation at $95{ }^{\circ} \mathrm{C}$ for $15 \mathrm{~min}$ and 40 cycles of $95{ }^{\circ} \mathrm{C}$ for $35 \mathrm{~s}, 56{ }^{\circ} \mathrm{C}$ for $30 \mathrm{~s}$ and $72{ }^{\circ} \mathrm{C}$ for 30 s. The specificity of the amplified product was verified by melting curve analysis. Expression levels of target genes were normalized to $\beta$-actin. Drug transporters' expression 
profiling was performed using $\mathrm{RT}^{2}$-Profiler PCR arrays (SABiosciences, Frederick, MD, USA) according to manufacturer's instructions.

\subsection{Immunoblotting}

$10^{7}$ cells were lysed in ice-cold RIPA buffer containing protease and phosphatase inhibitors (Pierce, Rockford, IL). $30 \mu \mathrm{g}$ of total protein were loaded on $12 \%$ polyacrylamide gel, electrophoresed and electroblotted onto a PVDF membrane. Membranes were then blocked in 5\% non-fat dry milk (Cell Signaling Technology (CST), Danvers, MA) in TBS containing $0.05 \%$ of Tween 20 (Pierce) and probed with anti-GUK or anti-AK2 antibody (SigmaAldrich) and appropriate HRP-conjugated secondary antibody (CST). SuperSignal ${ }^{\circledR}$ West Femto Maximum Sensitivity Chemiluminescent Substrate (Pierce) was used for signal detection by CCD camera. The membrane was then stripped with Restore ${ }^{\mathrm{TM}}$ Western Blotting Stripping Buffer (Pierce) according to manufacturer's instructions and reprobed with anti- $\beta$ actin antibody (CST) as a loading control. Monoclonal anti-HA peroxidase-conjugated antibody (Sigma) was used to verify efficiency of transient expression of HA-GUK.

\subsection{Data analysis and statistical procedures}

Unless otherwise indicated the data are presented as mean \pm S.D. from at least three independent experiments. Statistical evaluation was performed using GraphPad Prism version 5.00 for Windows (GraphPad Software). 


\section{Results}

\subsection{PMEG and PMEDAP uptake is not modified in resistant cells}

To determine the role of the transport in the resistance to PMEG and PMEDAP, we first screened the cells for the mRNA expression of various drug transporter proteins. Several genes were upregulated in resistant cell including P-gp (MDR1, ABCB1), whose expression was 5-fold higher in PMEG-resistant cells and 19-fold higher in PMEDAP-resistant cells compared to control, thus representing the greatest mRNA increase of all tested genes (Table 1). Since nucleotides are not recognized as P-gp substrates, we have checked for the effect of two specific and efficient P-gp inhibitors (LY335979, XR9576) on the sensitivity of resistant cells towards PMEG and PMEDAP. It turned out that P-gp inhibition by XR9576 did not enhance cytotoxicity of any of the tested compounds (Table 2). Experiments with LY335979 gave identical results (data not shown). These findings indicate that PMEG- and PMEDAPinduced resistance is most likely P-gp independent. This is further supported by the observation that both resistant cell lines retained sensitivity towards doxorubicin and etoposide, traditional P-gp substrates (Fig. 2A). On the other hand, MK571, a selective inhibitor of another class of resistance proteins known as MRPs, slightly reversed resistance of PMEDAP-resistant cells to PMEG (3-fold decrease in $\mathrm{IC}_{50}$ ) and possibly also to PMEDAP. However, $\mathrm{IC}_{50}$ for PMEDAP in resistant cells was not reached for up to $300 \mu \mathrm{M}$. Sensitivity of PMEG-resistant cells to either PMEG or PMEDAP remained unaffected by MK571. Interestingly, we also observed that the cross-resistance between PMEG and PMEDAP is not strictly reciprocal, i.e. PMEG-resistant cells are highly resistant to both PMEG and PMEDAP $\left(\mathrm{IC}_{50}>300 \mu \mathrm{M}\right)$, whereas PMEDAP-resistant cells retain certain degree of sensitivity to PMEG $\left(\mathrm{IC}_{50}=49 \mu \mathrm{M}\right)$ while it is highly resistant to PMEDAP $\left(\mathrm{IC}_{50}>300 \mu \mathrm{M}\right)($ Table 2$)$. This strongly suggests that in spite of the close structural resemblance of the two compounds 
(a single amino group difference) the molecular target responsible for the development of resistance may not be identical. Finally, we performed direct tracking of PMEG and PMEDAP in sensitive and resistant cells using radiolabeled compounds. As depicted in Figure 3, no significant variations in the intracellular concentration of PMEG or PMEDAP were found between sensitive and resistant cells for up to $45 \mathrm{~min}$ (Fig. 3A,C), irrespectively of the concentration used (Fig. 3B,D). It should be noted that this assay reflects total intracellular concentration of both the parent compounds and their metabolites.

\subsection{PMEG and PMEDAP are not phosphorylated in resistant cells}

After excluding a major role of diminished drug uptake, intracellular phosphorylation of PMEG and PMEDAP was investigated. Incubation of the cells with $2.5 \mu \mathrm{M}\left[{ }^{3} \mathrm{H}\right] \mathrm{PMEG}$ or 15 $\mu \mathrm{M}\left[{ }^{3} \mathrm{H}\right] \mathrm{PMEDAP}$ for $24 \mathrm{~h}$ resulted in a complete absence of PMEGp and PMEGpp in PMEG-resistant cells (Fig. 4B) as well as PMEDAPp and PMEDAPpp in PMEDAP-resistant cells (Fig. 4D). All metabolites were detectable in sensitive cells (Fig. 4A,C). These data indicate a block at the level of nucleoside monophosphate kinases. Further in vitro experiments with crude cellular extracts confirmed the incapacity of PMEG-resistant cells to phosphorylate PMEG as well as GMP (Table 3), clearly pointing to GUK to be responsible for the resistance. On the other hand, phosphorylation of PMEG was largely preserved in PMEDAP-resistant cells. Unfortunately, PMEDAP metabolites could not be detected in this cell-free assay. However, the metabolism of AMP (a natural substrate for AK) demonstrated that phosphorylation rate was slightly depressed in PMEDAP-resistant cells while it remained unaffected in PMEG-resistant cells (Table 3). Resistance to PMEDAP therefore appears to be dependent on AK although this effect is much weaker compared to PMEG vs. GUK. Impairment of AK in PMEDAP-resistant cells is supported by the observation that cladribine, a nucleotide analogue that also uses $\mathrm{AK}$ to its metabolic activation, was 10 times less 
cytotoxic in PMEDAP-resistant cells compared to sensitive or PMEG-resistant cells. On the other hand, the cytotoxicity of 5-fluoro-2'-deoxyuridine (FUDR), an analogue that requires neither GUK nor AK to its activation, was not affected in any of the two resistant cell lines (Fig. 2B).

\subsection{Expression of GUK and AK2 is decreased in resistant cells}

To determine whether the lack of phosphorylating capacity is due to decreased expression of the respective activating kinases (GUK for PMEG, AK2 for PMEDAP) or rather their defective catalytic activity, mRNA and protein levels of GUK and AK2 were quantified. We found an approx. 40\% drop in GUK mRNA expression in both resistant cell lines whereas AK2 expression was only decreased in PMEDAP-resistant cells (50\% of control level) (Fig. 5A). Protein levels appeared to be influenced in a similar manner although GUK protein was poorly detectable by immunoblotting due to its relatively low abundance compared to AK2 (Fig. 5B).

\subsection{Catalytic activity of GUK from PMEG-resistant cells is impaired due to point mutations}

To determine possible mutations leading to changes in catalytic activities, the genes encoding both GUK and AK2 were isolated from the sensitive and resistant cells, cloned into mammalian expression vector and sequenced. No changes in primary sequences of both A and B AK2 isoforms isolated from PMEDAP resistant and sensitive cells were found. In contrast, GUK isolated from PMEG-resistant cells revealed two point mutations $\mathrm{S}^{35} \mathrm{~N}$ and $\mathrm{V}^{168} \mathrm{~F}$ (SV/NF GUK) (Fig. 6). According to the 3-D structure of highly similar mouse GUK, sharing $93 \%$ homology with human GUK, it is likely that both identified mutations affect the CORE domain of GUK (Sekulic et al., 2002). The $S^{35}$ lies within the hinge 1 connecting 
NMP-binding and CORE regions and $\mathrm{V}^{168}$ lies in helix 7 within the CORE domain. As both residues $\mathrm{S}^{35}$ and $\mathrm{V}^{168}$ are highly conserved among GUK genes we hypothesized that at least one of these mutations negatively affects catalytic activity of GUK thus conferring PMEG resistance. To verify this, the PMEG resistant cells were transfected with the wtGUK and SV/NF GUK expression vectors. The levels of expression of both wt and SV/NF GUK proteins in transfected cells were determined by immunoblotting using antibody against HA (Fig. 7A) and anti-GUK (Fig. 7B). We observed a 20-fold increase in GMP phosphorylating activity and 33-fold increase in PMEG phosphorylating activity in PMEG-resistant cells transfected with wtGUK DNA whereas the cells transfected with the SV/NF GUK showed only a minor increase (2.5-fold for GMP and no change for PMEG as a substrate) (Table 4). In addition to the re-established cellular phosphorylation activity, transfection of resistant cells with wtGUK DNA restored the sensitivity to the cytotoxic effects of PMEG, which is evidenced by the drop of $\mathrm{IC}_{50}$ for PMEG from more than $300 \mu \mathrm{M}$ to $12 \mu \mathrm{M}$ (Table 4).

\section{Discussion}

This work elucidates the mechanisms leading to the resistance of T-lymphoblastic cells to the cytotoxic acyclic nucleotide PMEG, which has potential as new antilymphoma drug. Besides PMEG, its close structural congener PMEDAP was also investigated for comparative purposes. Moreover, PMEDAP-induced resistance was already addressed in the work of Zápotocký et al. [12] indicating that MRP4 and MRP5 may be involved in the development of resistance in CCRF-CEM cells and in PMEDAP-treated SD/Cub rats. In that particular study, the resistance was induced by continuous exposure of the cells and the animals to a fixed concentration of PMEDAP (corresponding to the initial $\mathrm{IC}_{50}$ ) for the whole 
selection period. Contrary to that we have now prepared cells resistant to much higher concentrations of PMEG and PMEDAP, respectively (40-100x initial $\left.\mathrm{IC}_{50}\right)$. Under the conditions of our study, no changes in MRP4 or MRP5 mRNA were found in either PMEGor PMEDAP-resistant cells. This apparent discrepancy can signify that the changes in MRP expression are more important at early phases of resistance development whereas other mechanisms predominate later on. Despite the lack of MRP mRNA upregulation, our experiments with MRP inhibitor MK-571 indicated that MRP transporters indeed affect PMEDAP cytotoxicity in PMEDAP-resistant cells. This can be possibly explained by the alterations in MRP function. On the other hand, PMEG- resistant cells were found to be fully independent on MRP proteins. The role of MDR1 protein (P-gp) was also ruled out by means of specific P-gp inhibitors, in spite of the fact that the initial expression analysis showed significant and puzzling increase in P-gp mRNA in both resistant cell lines. Nevertheless, Pgp mRNA overexpression did not result in the development of multidrug-resistance phenotype as documented by sustained sensitivity of the cells to the typical P-gp substrates (doxorubicin, etoposide) [19]. Direct measurements of intracellular concentrations of PMEG confirmed the assumption that the resistance is not due to changes of drug uptake. In case of PMEDAP, approximately 4-fold decrease in intracellular levels of PMEDAP was detected in PMEDAP-resistant cells compared to sensitive cells in a 24 h-experiment designed primarily to study the intracellular metabolism. Interestingly, this effect was not observed in a short term transport study (for up to 45 min) suggesting that PMEDAP enters PMEDAP-resistant cells rather efficiently but it is slowly expelled from the cells at later time points. This would be consistent with the above discussed role of MRP transporters in this process, however, more experiments would be necessary to confirm this hypothesis.

Possible defects in the metabolic activation of PMEG and PMEDAP to the corresponding diphosphates (dNTP analogues) were also investigated. It is known that 
resistance to nucleoside analogs such as for example cladribine often results from decreased levels of phosphorylated forms. This can be due to decreased activity of phosphorylating kinases and/or increased activity of 5'-nucleotidases (5-NT) [13]. We have found that PMEG and PMEDAP mono- and diphosphates were absent as well. The eventuality of enhanced dephosphorylation can be ruled out since the phosphate-mimicking phosphonic group of PMEG and PMEDAP resists hydrolysis by 5-NTs. We have therefore focused on phosphorylating kinases that have been previously described in our group to catalyze PMEGp and PMEDAPp formation - GUK and AK2, resp. [8,9]. The fact that each of the two compounds uses a different enzyme for their first-step phosphorylation would give grounds for the absence of a complete cross-resistance between each other. Expression of the two kinases was somewhat depressed in resistant cells but not to the extent that would explain a complete loss of phosphorylating capacity. Therefore, we assumed there might be some alterations in the catalytic activity of these proteins possibly due to changes in primary sequence, abnormal posttranslational modifications or other mechanisms. Upon isolation and sequencing of GUK gene from PMEG-resistant cells, we identified two point mutations $\mathrm{S}^{35} \mathrm{~N}$ and $\mathrm{V}^{168} \mathrm{~F}$ compared to GUK isolated from the PMEG-sensitive cells. As no high-resolution structure of human GUK is available so far, we used the crystallographic structure of mouse GUK to localize $\mathrm{S}^{35} \mathrm{~N}$ and $\mathrm{V}^{168} \mathrm{~F}$ mutations within the tertiary structure of the enzyme. It is believed that due to high sequence similarity between mouse and human GUKs (88\% identity, 93\% homology) the structural information gained on the mouse GUK is directly transferable to the human enzyme $[20,21]$. Assuming that this hypothesis is correct, the $S^{35}$ residue occurs in the hinge connecting the helix 1 of CORE region and the helix 2 of NMP-binding region. $\mathrm{S}^{35}$ is highly conserved within the primary structure of GUK and does not change from bacteria to human. The $\mathrm{V}^{168} \mathrm{~F}$ mutation occurs within the helix 7 of the CORE region and this residue is replaced with isoleucine in porcine or bovine GUKs or leucine in bacterial GUK. 
Interestingly, a mutation in a close proximity of $\mathrm{S}^{35}$ of mouse GUK has been proposed to be responsible for resistance to 6-thioguanine [21]. In that work Ardiani et al. substituted serine 37 and three resulting mutants $\mathrm{S}^{37} \mathrm{~A}, \mathrm{~S}^{37} \mathrm{~T}$ and $\mathrm{S}^{37} \mathrm{Y}$ phosphorylated GMP but not 6 -TG. We isolated GUK double mutant directly from the PMEG resistant cells and proved that the $\mathrm{S}^{35} \mathrm{NV}^{168} \mathrm{~F}$ GUK is inactive not only towards PMEG but also GMP. These mutations in human GUK explained the mechanism of PMEG resistance. On the other hand, PMEDAPphosphorylating kinase AK2 possessed wild-type genotype in both PMEG- and PMEDAPresistant CCRF-CEM cells. Therefore, no changes in the conformation of AK2 protein and its catalytic activity can be anticipated and resistance to PMEDAP is clearly conferred by the mechanisms distinct from mutations in the activating kinase. Whether a 50\% decrease in the AK2 protein content can itself explain the absence PMEDAP metabolism remains speculative. However, PMEDAP is only a poor substrate for AK2 $(\mathrm{Km}=670 \mu \mathrm{M})$ [9], which is probably the main reason why PMEDAP phosphorylation could not be detected in cell-free extracts. Therefore, PMEDAP metabolism could be more affected by the decreased expression of AK compared to PMEG vs. GUK. In addition, diminished intracellular concentration of PMEDAP in PMEDAP-resistant cells (Fig. 4) further lowers the amount of the substrate available for AK.

In conclusion, we have shown here that the potential anticancer drugs PMEG and PMEDAP are capable of inducing resistance upon prolonged treatment. PMEG-induced resistance is not due to the modifications in its uptake/efflux but solely due to a decreased capacity of resistant cells to metabolically activate (phosphorylate) the drug. This is largely conferred by the impaired catalytic function of GUK resulting from two point mutations and to a much lesser extent by the down-regulation of GUK. Resistance to PMEDAP is clearly distinct from that of PMEG and do not involve changes in the primary structure of the 
activating kinase. We have also shown that PMEG- and PMEDAP-induced resistance is not that of multidrug-resistance phenotype and is unlikely to affect other commonly used anticancer drugs. These findings have implications in clinical settings.

\section{Acknowledgement}

The work was supported by Center for New Antineoplastics and Antivirals \#1M0508 of Czech Ministry of Education, Youth and Sports and IOCB \& Gilead Sciences Research Center. The authors would like to thank Dr. T. Elbert for purification of $\left[\mathrm{U}^{-14} \mathrm{C}\right] \mathrm{GMP}$ and preparation of radiolabeled PMEG and PMEDAP, Dr. T. Cihlar for kindly providing us with P-gp and MRP inhibitors and L. Tovchigrechko, K. Müllerová for excellent technical assistance.

\section{List of references}

[1] De Clercq E, Holý A. Acyclic nucleoside phosphonates: a key class of antiviral drugs. Nat Rev Drug Discov 2005;4:928-40.

[2] De Clercq E, Andrei G, Balzarini J, Hatse S, Liekens S, Naesens L, Neyts J, Snoeck R. Antitumor potential of acyclic nucleoside phosphonates. Nucleosides Nucleotides $1999 ; 18: 759-71$.

[3] Bobková K, Otová B, Marinov I, Mandys V, Panczak A, Votruba I, Holý A. Anticancer effect of PMEDAP--monitoring of apoptosis. Anticancer Res 2000;20:1041-7.

[4] Mertlíková-Kaiserová H, Votruba I, Matoušová M, Holý A, Hájek M. Role of caspases and CD95/Fas in the apoptotic effects of a nucleotide analog PMEG in CCRF-CEM cells. Anticancer Res 2010;30:2791-8. 
[5] Reiser H, Wang J, Chong L, Watkins WJ, Ray AS, Shibata R, Birkus G, Cihlar T, Wu S, Li B, Liu X, Henne IN, Wolfgang GH, Desai M, Rhodes GR, Fridland A, Lee WA, Plunkett W, Vail D, Thamm DH, Jeraj R, Tumas DB. GS-9219--a novel acyclic nucleotide analogue with potent antineoplastic activity in dogs with spontaneous non-Hodgkin's lymphoma. Clin Cancer Res 2008;14:2824-32.

[6] Valeriánová M, Votruba I, Holý A, Mandys V, Otová B. Antitumour activity of N6substituted PMEDAP derivatives against T-cell lymphoma. Anticancer Res 2001;21:2057-64. [7] Holý A, Votruba I, Merta A, Černý J, Veselý J, Vlach J, Šedivá K, Rosenberg I, Otmar M, Hřebabecký H, et al. Acyclic nucleotide analogues: synthesis, antiviral activity and inhibitory effects on some cellular and virus-encoded enzymes in vitro. Antiviral Res 1990;13:295-311. [8] Krejčová R, Horská K, Votruba I, Holý A. Interaction of guanine phosphonomethoxyalkyl derivatives with GMP kinase isoenzymes. Biochem Pharmacol 2000;60:1907-13.

[9] Krejčová R, Horská K, Votruba I, Holý A. Phosphorylation of Purine (Phosphonomethoxy)alkyl Derivatives by Mitochondrial AMP Kinase (AK2 Type) from L1210 Cells. Coll Czech Chem Commun 2000;65:1653-1668

[10] Pauwels EK, Erba P, Mariani G, Gomes CM. Multidrug resistance in cancer: its mechanism and its modulation. Drug News Perspect 2007;20:371-7.

[11] Dallas S, Schlichter L, Bendayan R. Multidrug resistance protein (MRP) 4- and MRP 5mediated efflux of 9-(2-phosphonylmethoxyethyl)adenine by microglia. J Pharmacol Exp Ther 2004;309:1221-9

[12] Zápotocký M, Hanzalová J, Starková J, Votruba I, Holý A, Otová B. Experimental therapy with 9-[2-(phosphonomethoxy)ethyl]-2,6-diaminopurine (PMEDAP): origin of resistance. Folia Biol (Praha) 2007;53:79-84.

[13] Lotfi K, Juliusson G, Albertioni F. Pharmacological basis for cladribine resistance. Leuk Lymphoma 2003;44:1705-12. 
[14] Hunsucker SA, Mitchell BS, Spychala J. The 5'-nucleotidases as regulators of nucleotide and drug metabolism. Pharmacol Ther 2005;107:1-30.

[15] Zhao Y, Shen S, Guo J, Chen H, Greenblatt DY, Kleeff J, Liao Q, Chen G, Friess H, Leung PS. Mitogen-activated protein kinases and chemoresistance in pancreatic cancer cells. J Surg Res 2006;136:325-35.

[16] Holý A. Synthesis of acyclic nucleoside phosphonates. Curr Protoc Nucleic Acid Chem 2005; Chapter 14:Unit 14.2.

[17] Elbert T, Břehová P, Holý A. The preparation of ${ }^{3} \mathrm{H}$-labeled acyclic nucleoside phosphonates and study of their stability. 2010;75: 757-766.

[18] Hájek M, Cvilink V, Votruba I, Holý A, Mertlíková-Kaiserová H. Distinct modulation of telomere length in two T-lymphoblastic leukemia cell lines by cytotoxic nucleoside phosphonates PMEG and PMEDAP. Eur J Pharmacol 2010;643:6-12.

[19] Lum BL, Gosland MP, Kaubisch S, Sikic BI. Molecular targets in oncology: implications of the multidrug resistance gene. Pharmacotherapy 1993;13:88-109.

[20] Sekulic N, Shuvalova L, Spangenberg O, Konrad M, Lavie A. Structural characterization of the closed conformation of mouse guanylate kinase. JBC 2002: 30236-30243.

[21] Ardiani A, Goyke A, Black ME. Mutation at serine 37 in mouse guanylate kinase confer resistance to 6-thioguanine Protein Eng. Des. Sel. 2009;22:225-232. 


\section{Tables}

Table 1. Gene expression profiling on drug transporters ${ }^{*}$ in PMEG- and PMEDAP-resistant cells. The table shows the list of genes that have been upregulated in at least one of the two resistant cell lines compared to sensitive CCRF-CEM cells.

\begin{tabular}{|c|c|c|c|c|}
\hline \multirow[b]{2}{*}{ Symbol } & \multirow[b]{2}{*}{ Description } & \multirow[b]{2}{*}{ Gene name } & \multicolumn{2}{|c|}{ Fold up-regulation } \\
\hline & & & $\begin{array}{l}\text { PMEG- } \\
\text { res }\end{array}$ & $\begin{array}{l}\text { PMEDAP- } \\
\text { res }\end{array}$ \\
\hline $\mathrm{ABCA} 2$ & $\begin{array}{l}\text { ATP-binding cassette, sub-family A } \\
\text { (ABC1), member } 2\end{array}$ & $\mathrm{ABC} 2$ & 3.5 & 4.4 \\
\hline $\mathrm{ABCB} 1$ & $\begin{array}{l}\text { ATP-binding cassette, sub-family B } \\
\text { (MDR/TAP), member } 1\end{array}$ & $\mathrm{ABC} 20 / \mathrm{CD} 243$ & 4.7 & 19.4 \\
\hline MVP & Major vault protein & LRP/VAULT1 & 2.6 & 2.3 \\
\hline SLC5A4 & $\begin{array}{l}\text { Solute carrier family } 5 \text { (low affinity } \\
\text { glucose cotransporter), member } 4\end{array}$ & SAAT1/SGLT3 & 2.1 & 1.1 \\
\hline $\mathrm{ABCB} 6$ & $\begin{array}{l}\text { ATP-binding cassette, sub-family B } \\
\text { (MDR/TAP), member } 6\end{array}$ & $\mathrm{ABC} / \mathrm{ABC} 14$ & 1.0 & 2.0 \\
\hline $\mathrm{ABCD} 1$ & $\begin{array}{l}\text { ATP-binding cassette, sub-family D } \\
\text { (ALD), member } 1\end{array}$ & ABC42/ALD & 1.8 & 2.2 \\
\hline ATP6V0C & $\begin{array}{l}\text { ATPase, } \mathrm{H}+\text { transporting, lysosomal } \\
16 \mathrm{kDa}, \mathrm{V} 0 \text { subunit c }\end{array}$ & ATP6C/ATP6L & 1.3 & 2.0 \\
\hline SLC15A2 & $\begin{array}{l}\text { Solute carrier family } 15(\mathrm{H}+/ \text { peptide } \\
\text { transporter), member } 2\end{array}$ & PEPT2 & 1.1 & 3.6 \\
\hline SLCO2A1 & $\begin{array}{l}\text { Solute carrier organic anion transporter } \\
\text { family, member } 2 \mathrm{~A} 1\end{array}$ & OATP2A1/PGT & 1.8 & 3.6 \\
\hline TAP1 & $\begin{array}{l}\text { Transporter } 1 \text {, ATP-binding cassette, } \\
\text { sub-family B (MDR/TAP) }\end{array}$ & $\mathrm{ABC} 17 / \mathrm{ABCB} 2$ & 1.1 & 2.1 \\
\hline
\end{tabular}

${ }^{*} \mathrm{RT}^{2}$ Profiler ${ }^{\mathrm{TM}}$ PCR Array Human Drug Transporters (PAHS-070D, SABiosciences) enabling the analysis of mRNA for 84 transporter genes. 
Table 2. Sensitivity of resistant cells to PMEG and PMEDAP and the influence of MDR and MRP inhibitors. Data are expressed as $\mathrm{IC}_{50}(\mu \mathrm{M})$ obtained from XTT cytotoxicity test and represent means from three independent experiments.

\begin{tabular}{lcccccc}
\hline \multirow{2}{*}{ Cell line } & \multicolumn{3}{c}{ PMEG } & \multicolumn{3}{c}{ PMEDAP } \\
\cline { 2 - 7 } & - & $+\mathrm{XR}$ & $+\mathrm{MK}$ & - & $+\mathrm{XR}$ & $+\mathrm{MK}$ \\
\hline Control (WT) & $2.7 \pm 0.2$ & $3.3 \pm 0.3$ & $3.5 \pm 0.6$ & $19.0 \pm 2.8$ & $31.0 \pm 9.1$ & $19.4 \pm 0.4$ \\
PMEG-res & $>300$ & $>300$ & $>300$ & $>300$ & $>300$ & $>300$ \\
PMEDAP-res & $49.0 \pm 7.1$ & $49.3 \pm 6.9$ & $17.8 \pm 0.8^{* *}$ & $>300$ & $>300$ & $>300$ \\
\hline
\end{tabular}

XR - XR9576 (P-gp inhibitor), MK - MK576 (MRP inhibitor), **p<0.01 vs. resistant cells w/o inhibitor (ANOVA) 
Table 3. In vitro phosphorylating capacity of crude cellular extracts from sensitive and resistant CCRF-CEM cells. Data are means from three independent experiments.

\begin{tabular}{lcccccc}
\hline \multirow{2}{*}{ Cell line } & \multicolumn{2}{c}{ PMEG } & \multicolumn{2}{c}{ GMP } & \multicolumn{2}{c}{ AMP } \\
\cline { 2 - 7 } & $\mathrm{K}_{\mathrm{m}}{ }^{\mathrm{a}}$ & $\mathrm{V}_{\max } \mathrm{b}$ & $\mathrm{K}_{\mathrm{m}}$ & $\mathrm{V}_{\max }$ & $\mathrm{K}_{\mathrm{m}}$ & $\mathrm{V}_{\max }$ \\
\hline Control (WT) & $140 \pm 17$ & $0.17 \pm 0.01$ & $15 \pm 3$ & $50 \pm 3$ & $6 \pm 3$ & $355 \pm 45$ \\
PMEG-res & $1253 \pm 195^{* *}$ & $0.033 \pm 0.01^{* *}$ & $270 \pm 151^{*}$ & $3 \pm 2^{* *}$ & $7 \pm 3$ & $424 \pm 37$ \\
PMEDAP-res & $104 \pm 15$ & $0.11 \pm 0.01^{* *}$ & $8 \pm 2$ & $33 \pm 2^{* *}$ & $3 \pm 4$ & $219 \pm 51^{*}$ \\
\hline${ }^{\mathrm{a}}[\mu \mathrm{M}] ;{ }^{\mathrm{b}}\left[\mathrm{nmol}^{-1} \mathrm{~min}^{-1} \mathrm{mg}^{-1}\right],{ }^{*} \mathrm{p}<0.05,{ }^{* *} \mathrm{p}<0.01$ vs. control (ANOVA) & &
\end{tabular}


Table 4. Catalytic activity of PMEG-resistant CCRF-CEM cells transfected with wtGUK and SV/NF GUK and their sensitivity to the cytotoxicity of PMEG.

\begin{tabular}{lccc}
\hline & $\begin{array}{c}\text { GMP } \\
\left(\mathrm{nmol}^{-1} \mathrm{~min}^{-1} \mathrm{mg}^{-1}\right)^{\mathrm{a}}\end{array}$ & $\begin{array}{c}\text { PMEG } \\
\left(\mathrm{nmol}^{-1} \mathrm{~min}^{-1} \mathrm{mg}^{-1}\right)^{\mathrm{b}}\end{array}$ & $\begin{array}{c}\text { PMEG } \mathrm{IC}_{50} \\
(\mu \mathrm{M})^{\mathrm{c}}\end{array}$ \\
\hline PMEG-res + wtGUK & $66.5 \pm 0.5^{* * * *}$ & $4.55 \pm 0.40^{* * * * *}$ & 12.6 \\
PMEG-res + SV/NF GUK & $8.4 \pm 1.1^{* * *}$ & $0.13 \pm 0.00$ & $>300$ \\
PMEG-res mock & $3.3 \pm 1.0$ & $0.14 \pm 0.02$ & $>300$ \\
sensitive (wt) cells & $19.6 \pm 0.6$ & $0.39 \pm 0.02$ & 1 \\
\hline
\end{tabular}

${ }^{* * *} \mathrm{p}<0.001$ vs. mock-transfected cells (One-Way ANOVA with Tukey's post-hoc test);

${ }^{\mathrm{a}} 100 \mu \mathrm{M}$ GMP, $30^{\circ} \mathrm{C}, 5 \mathrm{~min} ;{ }^{\mathrm{b}} 100 \mu \mathrm{M}$ PMEG, $30^{\circ} \mathrm{C}, 10 \mathrm{~min} ;{ }^{\mathrm{c}}$ XTT cytotoxicity test, $72 \mathrm{~h}$ post-transfection. 


\section{Figure captions}

Fig. 1. Structures of 9-[2-(phosphonomethoxyethyl)guanine] (PMEG) and 9-[2(phosphonomethoxyethyl)diaminopurine] (PMEDAP).

Fig. 2. Sensitivity of resistant cells to P-gp substrates (A) and other nucleoside analogs (B). Data are expressed as $\mathrm{IC}_{50}$ values $(\mathrm{nM})$ obtained from XTT cytotoxicity test and represent means from three independent experiments. FUDR - 5-fluoro-2'-deoxyuridine. $* * * p<0.01$ vs. sensitive cells (ANOVA).

Fig. 3. Uptake of $\left[{ }^{3} \mathrm{H}\right] \mathrm{PMEG}$ and $\left[{ }^{3} \mathrm{H}\right] \mathrm{PMEDAP}$ in sensitive and resistant CCRF-CEM cells. The time course of the intracellular transport was measured for up to $45 \min$ using $90 \mu \mathrm{M}$ PMEG (A) or $300 \mu \mathrm{M}$ PMEDAP (C). Dependence of the transport efficiency on extracellular concentration of PMEG (B) and PMEDAP (D) was measured at $t=30 \mathrm{~min}$.

Fig. 4. Intracellular phosphorylation of $\left[{ }^{3} \mathrm{H}\right] \mathrm{PMEG}$ and $\left[{ }^{3} \mathrm{H}\right] \mathrm{PMEDAP}$ in sensitive $(\mathrm{A}, \mathrm{C})$ and resistant (B,D) CCRF-CEM cells after $24 \mathrm{~h}$ incubation with $2.5 \mu \mathrm{M}$ PMEG and $15 \mu \mathrm{M}$ PMEDAP $\left(10 \mu \mathrm{Ci} / 10^{6}\right.$ cells). Representative chromatograms out of two independent experiments performed with the same results are shown. Identity of all peaks was confirmed using the authentic standards.

Fig. 5. Expression of GUK1 and AK2 in sensitive and resistant CCRF-CEM cells. mRNA expression (A) was quantified by RT-qPCR and normalized to reference genes. Data represent means out of 3-4 independent experiments \pm SD. ${ }^{*} \mathrm{p}<0.05,{ }^{* *} \mathrm{p}<0.01$ (One Way ANOVA 
with Tukey's post hoc test). Protein levels of GUK1 and AK2 were detected by immunoblotting (B). Blots are representative of two independent experiments performed.

Fig. 6. Amino acids alignment of GUK 1 isolated from PMEG sensitive (GUK1 wt) and PMEG-resistant (GUK PMEG-res) CCRF-CEM cells. Two point mutations, identified in GUK from PMEG-resistant cells are shown in a grey box.

Fig. 7. Immunoblot analysis confirming the overexpression of GUK1 in PMEG-resistant cells transfected with wtGUK (lanes 1,2), mutant SV/NF GUK (lanes 3,4) and mock transfected cells (lane 5). Antibodies against both HA-tag (panel A) and GUK protein (panel B) yielded the same results. 

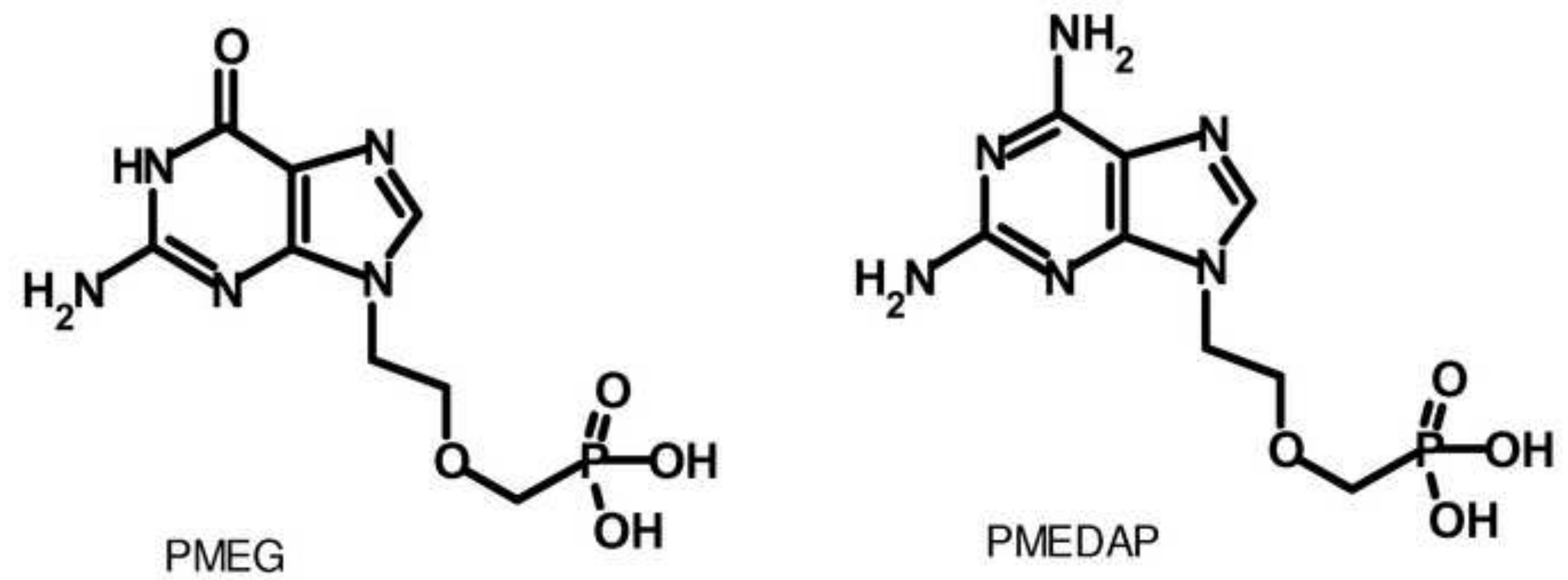
A

B
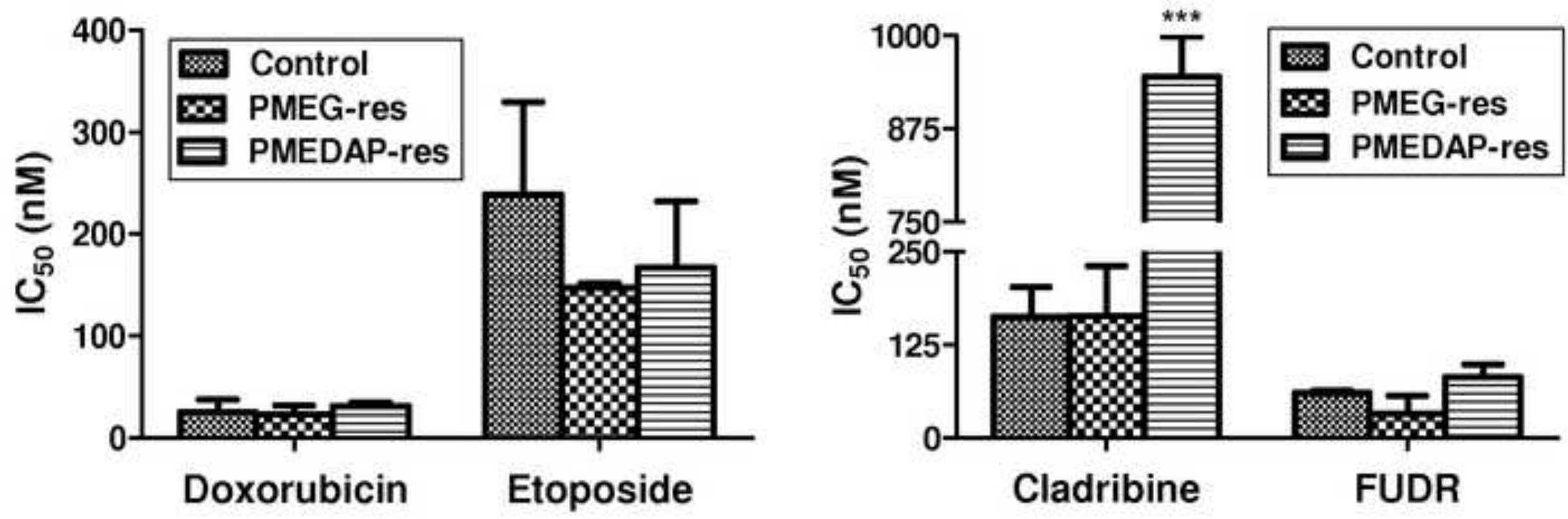
A

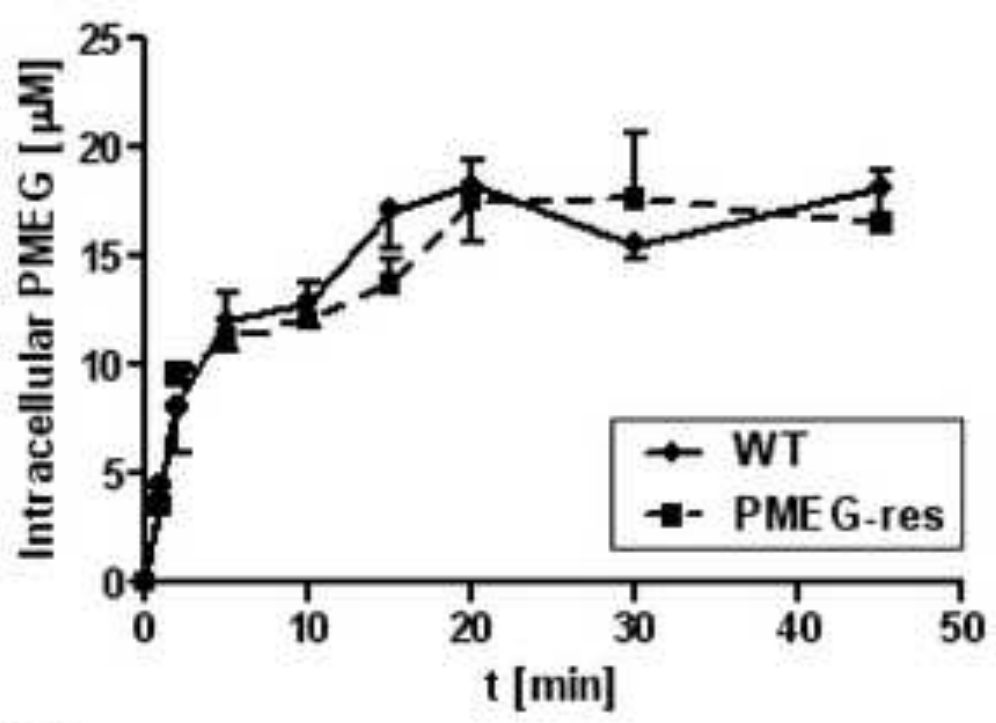

C

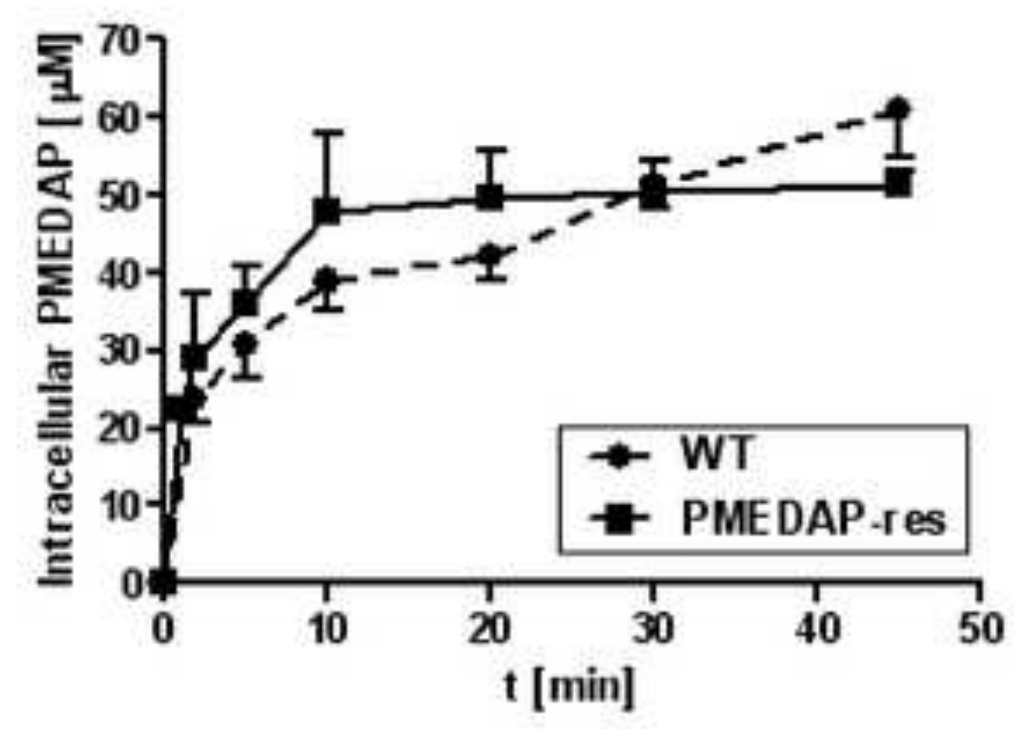

B
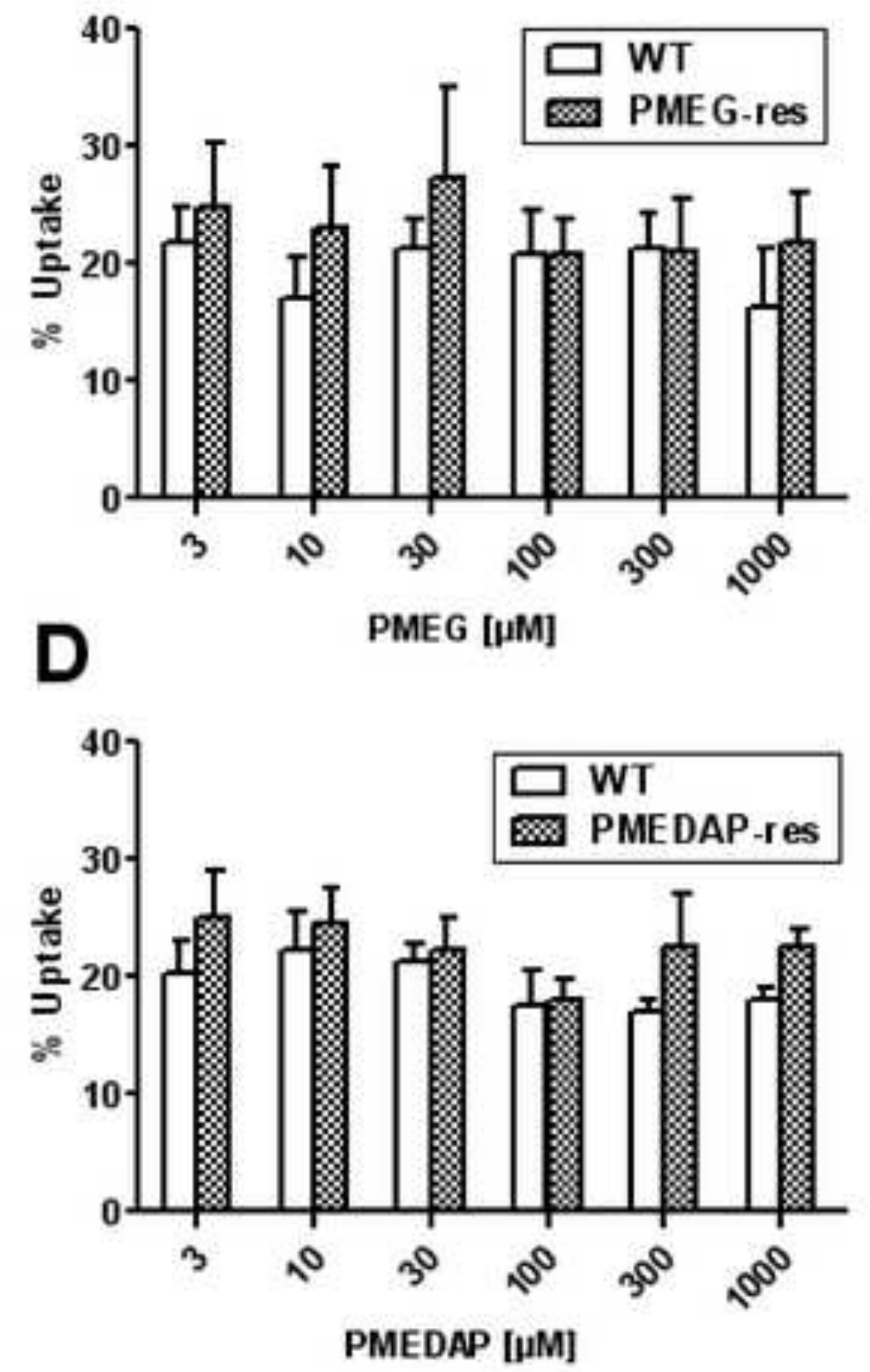

rage 30 ot 35 


\section{A}

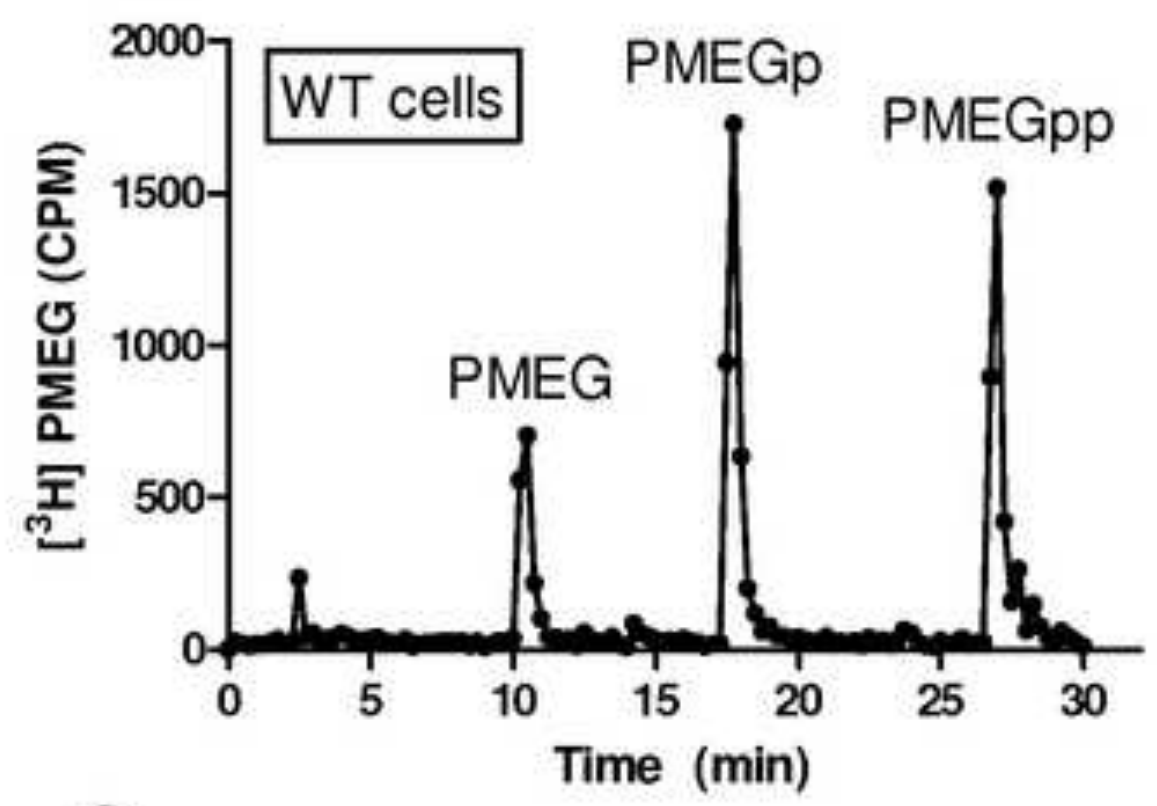

G

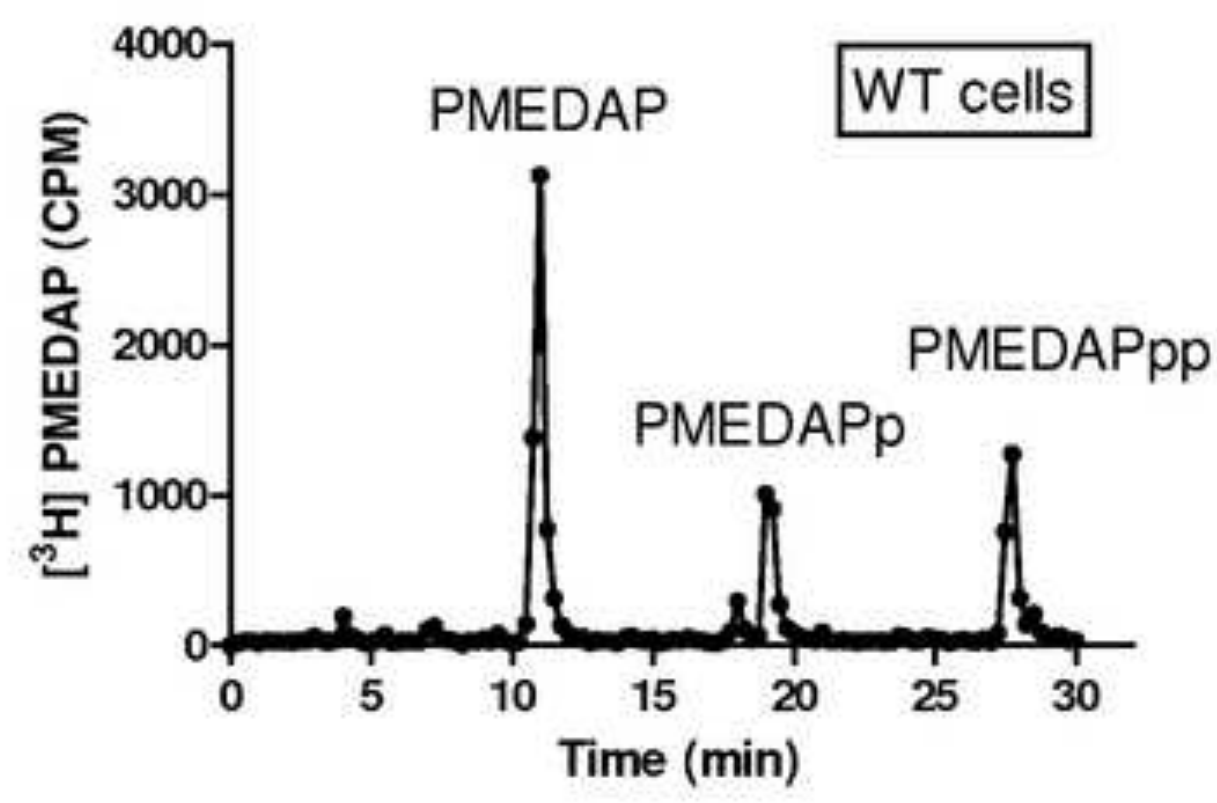

B

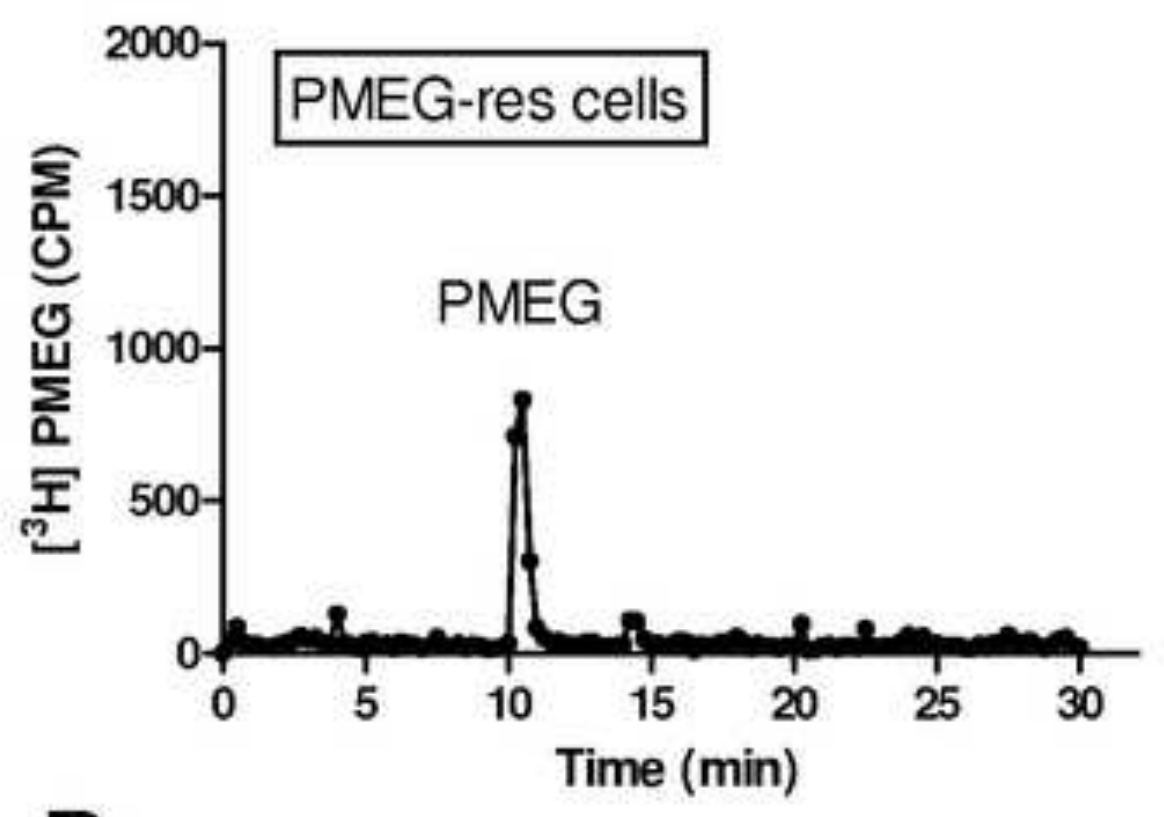

D

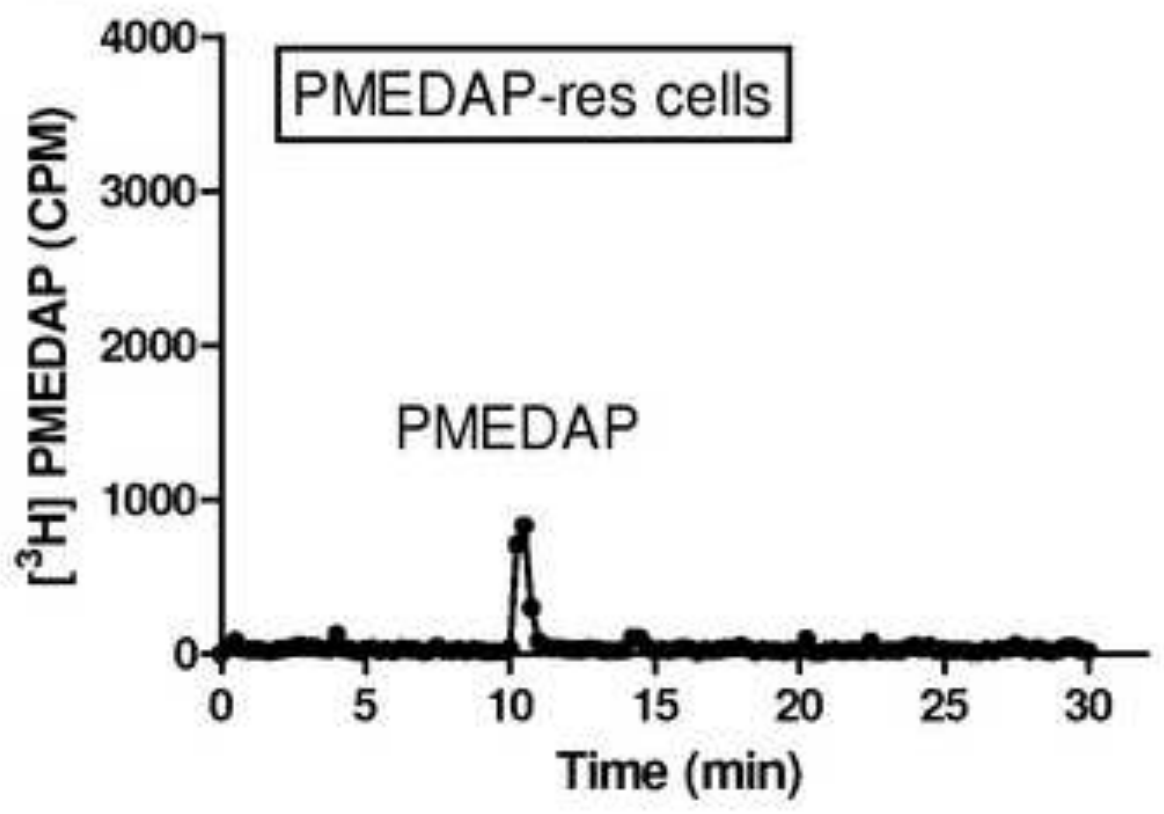

rage 31 oा 35 
A

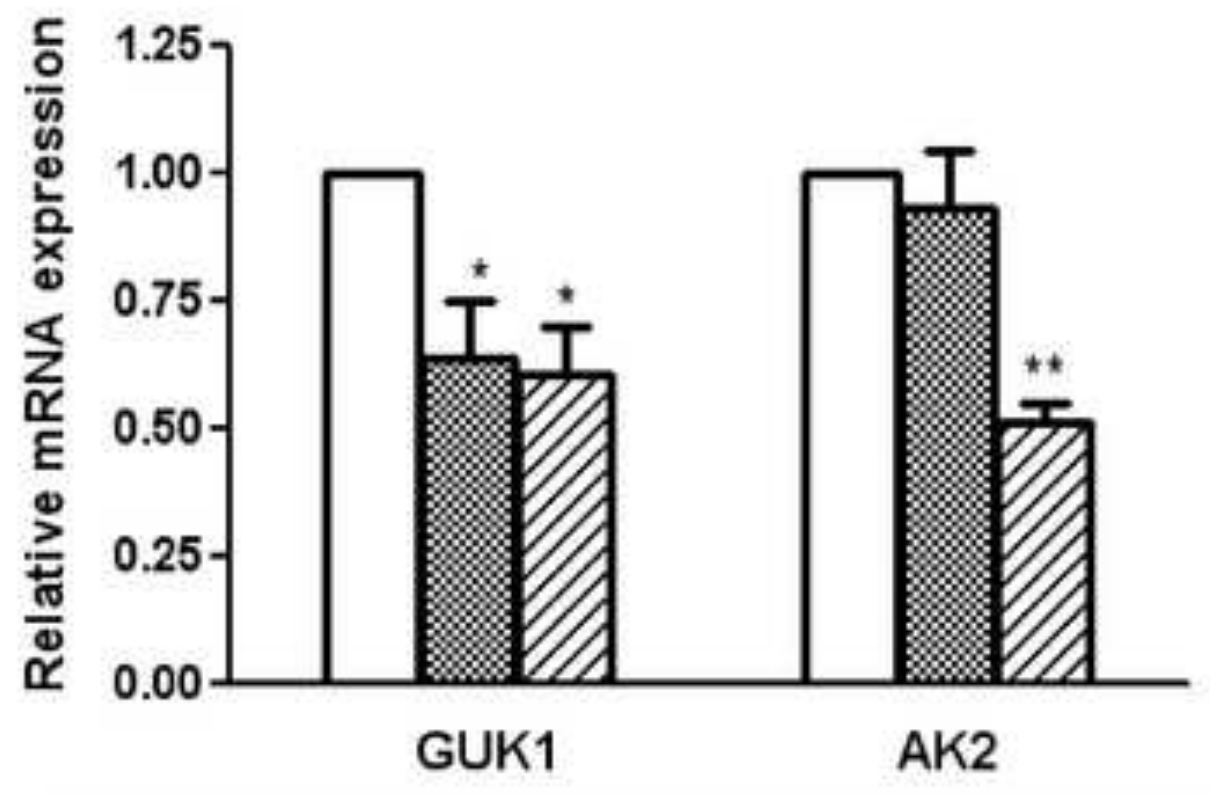

$\square$ WT $\approx$ PMEG-res 2 PMEDAP-res
B

$\mathrm{AK} 2$

(26 kDa)

GUK1

(22 kDa)

$\beta$-actin (42 kDa) 


\section{GUK1 wt GUK1 PMEG-res}

\section{GUK1 wt \\ GUK1 PMEG-res}

$\begin{array}{ll}\text { GUK1 } & \text { wt } \\ \text { GUK1 PMEG-res }\end{array}$

GUK1 wt

GUK1 PMEG-res
${ }^{1}$ MSGPRPVVLSGPSGAGKSTLLKRLLQEHSGIFGESVSHTTRNPRPGEENGKDYYEVTREV ${ }^{1}$ MSGPRPVVLSGPSGAGKSTLLKRLLQEHSGIFGENVSHTTRNPRPGEENGKDYYEVTREV

61 MQRDIAAGDE IEHAEE SGNLYGTSKVAVQAVQAMNRICVLDVDLQGVRNIKATDLRPIYI ${ }^{61}$ MQRDIAAGDE IEHAEF SGNLYGTSKVAVQAVQAMNR ICVLDVDLQGVRNIKATDLRPIYI

${ }^{121}$ SVQPP SLHVLEQRLRQRNTETEESLVKRLAAAQADMES SKEPGLFDVVI INDSLDQAYAE ${ }^{12.1}$ SVQPPSLHVLEQRLRQRNTETEESLVKRLAAAQADMESSKEPGLFDVEI INDSLDQAYAE

19: LKEALSEEIKKAQRTGA

${ }^{181}$ LKEALSEE IKKAQRTGA 


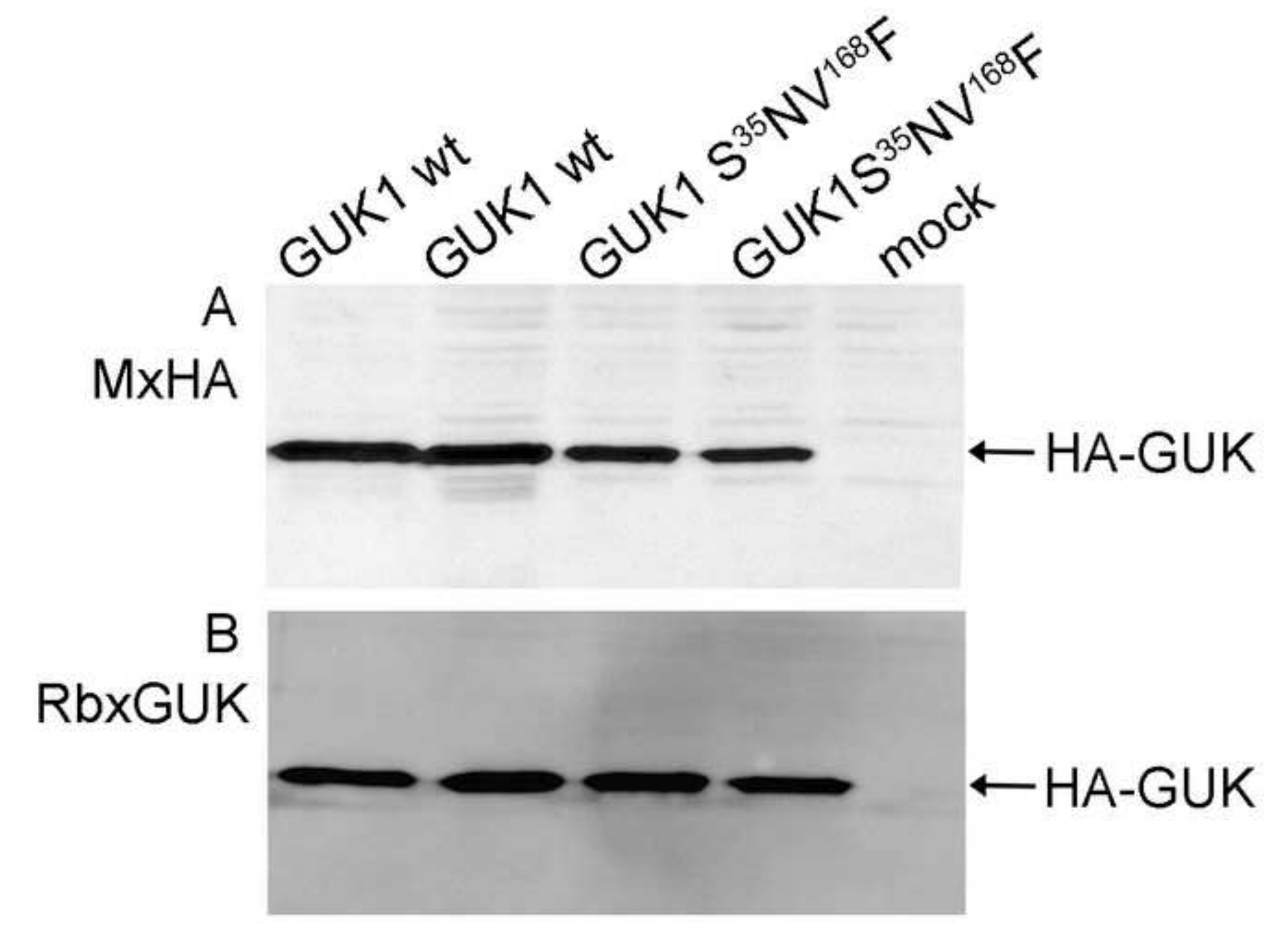


Resistance to PMEG due to mutations in guanylate kinase (GUK). Transfection of resistant cells with wtGUK restores their phosphorylating activity and sensitivity to the cytotoxic effects of PMEG.
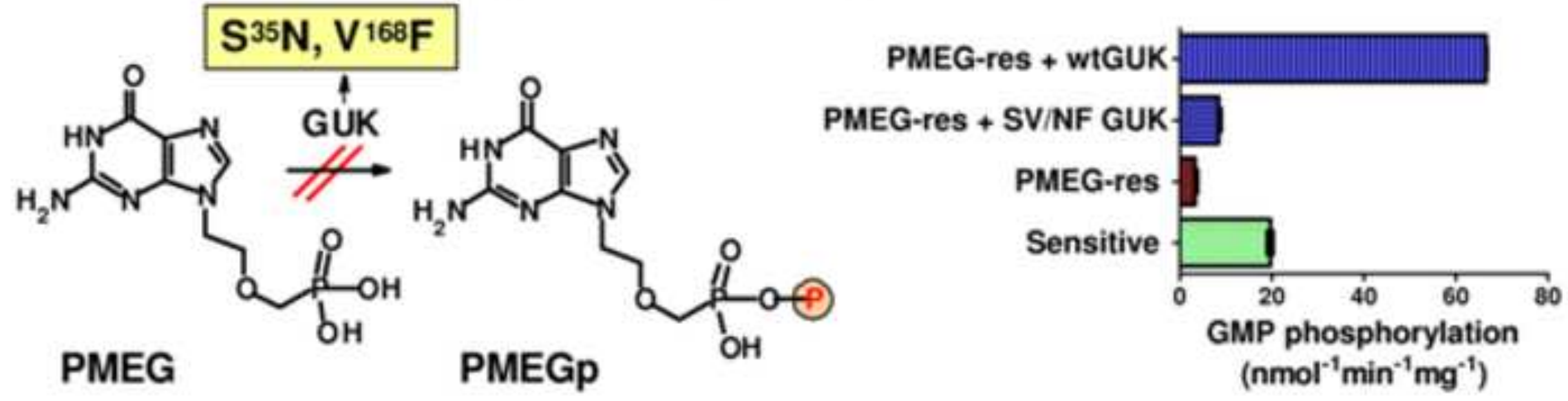